\title{
New Polish localities of two rare wasp species (Hymenoptera): Leucospis dorsigera Fabricius, 1775 (Chalcidoidea: Leucospidae) and Scolia hirta Schrank, 1781 (Vespoidea: Scoliidae)
}

\author{
Dawid MARCZAK ${ }^{*}$, Danuta PEPŁOWSKA-MARCZAK ${ }^{* *}$, Bogdan WiŚNIOWSKI $^{* * *}$ \\ and Tomasz HuFLEJT**** \\ * Kampinos National Park, Tetmajera 38, 05-080 Izabelin, Poland, University of Ecology and Management in Warsaw, \\ Department of Ecology, Wawelska 14, 02-061 Warszawa, Poland; \\ e-mail: dawid.marczak@gmail.com \\ **Kampinos National Park, Tetmajera 38, 05-080 Izabelin, Poland; \\ e-mail: d.marczak@kampinoski-pn.gov.pl \\ *** Ojców National Park, 32-047 Ojców 9, Poland; \\ e-mail: bogdan@isez.pan.krakow.pl \\ ****Museum and Institute of Zoology Polish Academy of Science, Wilcza 64, 00-679 Warszawa, Poland; \\ e-mail: thuflejt@miiz.waw.pl
}

\begin{abstract}
The paper presents new localities of two rare species of wasps (Hymenoptera): Leucospis dorsigera Fabr. (Chalcidoidea: Leucospidae) and Scolia hirta Schr. (Vespoidea: Scoliidae). Both species are highly endangered in relation to the disappearance of their habitats. Authors give several new sites of both species. For L. dorsigera the north-eastern limit of distribution in Europe moved more north.
\end{abstract}

Key words: Hymenoptera, Leucospis dorsigera, Scolia hirta, new localities, Poland, parasitic wasps

\section{INTRODUCTION}

Polish Red Data Book (Glowaciński et Nowacki 2004) contains 36 species of Hymenoptera, which are threatened or believed to be extinct. Research undertaken after the publication of the Polish Red Data Book provides new data on the occurrence of some of these species. Several new findings on the two of these species: Leucospis dorsigera Fabricius, 1775 and Scolia hirta Schrank, 1781, are presented in this study.

Leucospis dorsigera belongs to the family Leucospidae of the superfamily Chalcidoidea. The species is the only known representative of this family in Poland, so far. In Europe, Leucospidae are represented by four species: L. biguetina JURINE, 1807, L. dorsigera, L. gigas Fabricius, 1793 and $L$. intermedia Illiger, 1807 (Bouček 1959, 1974). The larvae of $L$. dorsigera are parasitoids of bee larvae from the family Megachilidae (Wiśniowski 2004), occasionaly also as a hyperparasitoid of Cerambycidae (Coleoptera) through Xoridinae (Hym., Ichneumonidae) (Hesami et al. 2005).

Leucospis dorsigera is endangered due to the disappearance of its preferred habitats: old, dying and sunlit trees and wooden buildings. The species figures on the Polish Red Data Book of Animals in the category VU - vulnerable species (Wiśniowski 2004).

In Europe, until recently, the species was known only from southern Europe, France, the south-western part of Germany, Austria, Hungary, Czech Republic, Slovakia, Ukraine and Moldova (Bouček 1959, 1974, Madl 1990). In the last two decades, several new site were found in Europe. This caused the shift of its distribution north. Madl (1989) and later Baur and Amiet (2000) found L. dorsigera in Austria and Switzerland. Pauly et al. (2002) found it in 
Belgium and Luxembourg. In the following years, Feitz et al. (2003) confirmed its presence in Luxembourg and Renneson (2005) in Belgium. Peeters and Kuper (2006) noted this species on the borderline of The Netherlands and Germany.

In Poland, Leucospis dorsigera was found for the first time at the end of the eighteenth century in Silesia (Panzer 1798). However, Bouček $(1959,1974)$ did not include this species in the Polish fauna. The occurrence of the species was confirmed by Szczepański (1964) based on two female specimens caught in 1947 in the village Niezgoda, Milicz district in the valley of Barycz river. The last statement of this species in Poland was included in the paper of Wiśniowski and Żyla (1996), where three new localities in southern Poland were presented: Lower Silesia - Glogówek, Western Beskidy Mountains - Wisla Malinka and Upper Silesia - Bytom.

Scolia hirta Schrank, 1781 belongs to the family Scoliidae of the superfamily Vespoidea. In Poland, Scoliidae are represented by two species - the rare Scolia hirta and the common S. sexmaculata (O. F. Müller, 1766) (= S. quadripunctata Fabricius, 1775) (PUŁAWSKI 1964). In Europe, the family is represented by 22 species classified into 7 genera, occurring mostly in the Mediterranean Region. The larvae of Scolia hirta are parasitoids of beetle larvae of the family Scarabaeidae (mainly Cetonia, Potosia, Epicometis and Anomala) (Banaszak 2004).

Scolia hirta prefers xerothermic grasslands. This species is endangered, because these habitats are disappearing as a result of natural succession of plant communities: open areas, which are usually the result of human activity, turn into woodlands when unmanaged for some period of time. That reduces the area suitable for the hosts of Scolia hirta, and as a consequence influences negatively the parasitoid. The species figures on the Polish Red Data Book of Animals in the category VU - vulnerable species (Banaszak 2004). According to Banaszak (2004), this species is threatened with extinction.

Scolia hirta is known from the western, southern and central parts of Europe as well as from Sweden and Norway (Fauna Europaea 2011). Recently it has been found in Lithuania (Rasomavicius et al. 2006).

In Poland, the species is known from 58 localities (Banaszak and Twerd 2009). Eighteen sites were recorded in the first half of the twentieth century, another 14 localities in the second half of the twentieth century, while further 26 were found in the first decade of the twenty-first century.

New LoCaLities

\section{Leucospis dorsigera Fabricius, 1775}

(Fig. 1)

Mazowiecka Lowland

Kampinos National Park, village Pociecha [DC89], 1 female laying eggs in a wooden beam (Fig. 1), 22.06.2011, obs. D. Peplowska-Marczak.

Podlasie Lowland

Sutno vic. Siemiatycze [FC49], 1 male caught on a dry meadow on gravel pit, 18.07.2006, leg. J. Sawoniewicz.

Małopolska Upland

"Góry Pieprzowe" Reserve near Sandomierz (EB51), 1 male caught on xerothermic grassland with Stipa capillata, 18.06.2008, leg. B. Wiśniowski.

Lubelska Upland

Poleski National Park: Bagno Splawy near Zahucze Stare (FB49), 1 female caught on a dry meadow, 7.06.2007, leg. W. Piotrowski. 
Roztocze Upland

Guciów near Obrocz (FB40), 1 female caught on a wooden building, 6.07.2006, leg. B. Wiśniowski.

\section{Sandomierska Lowland}

Forest Inspectorate Nowa Dęba, Forest District Berówka, compartment 46 (EA59), 1 female caught in forest planting surrounded by old oak trees, 22.07.2006, leg. T. Huflejt, coll. Museum and Institute of Zoology PAS.

Dębica-Pustynia (EA43) 1 female caught in herbal vegetation, 19.07.2008, leg. T. Huflejt, coll. Museum and Institute of Zoology PAS

Brzyska Wola near Leżajsk (FA17), 1 female and 1 male caught on a flowering meadow, 30.07.2008, leg. T. Huflejt, Museum and Institute of Zoology PAS;

Chwałowice near Radomyśl on the San River (EB62), 1 male caught in a flowery meadow, 3.08.2009, leg. T. Huflejt, coll. Museum and Institute of Zoology PAS.

\section{Scolia hirta Schrank, 1781}

\section{Baltic Coast}

Wolin National Park, Wiselka (VV67), 1 female, 11.08.2007, leg. M. Borowiec and M. Poprawska.

Mazurian Lakeland

Forestry Inspectorate Jedwabno, Muszaki (DE34), 1 female visiting flowers in the plant community Koelerion glaucae, 12.07.2007, obs. D. Marczak.

Podlasie Lowland

Biebrza National Park, ad Budy (FE01), 1 female, 24.07.2009, leg. J. M. Gutowski.

Mazowiecka Lowland

Kampinos Forest: 1 female 17.07.1955, leg. R. Trojan, coll. Museum and Institute of Zoology PAS;

Kampinos National Park: Niepust (DC89), 1 female visiting flowers of Solidago sp., 7.08.2007, leg. A. Liana, coll. Museum and Institute of Zoology PAS, 1 female visiting flowers of Thymus sp., 7.08.2007, obs. A. Liana; Lomna Las (DD80), 1 female visiting flowers of Mentha longifolia, 8.09.2009, leg T. Huflejt, coll. Museum and Institute of Zoology PAS, 1 male visiting flowers of Mentha longifolia, 10.08.2010, obs. T. Huflejt; Niepust (DC89), 1 female visiting flowers in the plant community Koelerion glaucae (phot. 2), 02.07.2011, obs. D. Marczak.

\section{Małopolska Upland}

„Góry Pieprzowe"Reserve near Sandomierz (EB51), 1 male, 1.07.2008, 2 males, 17.08.2008, caught on xerothermic grassland with Stipa capillata, leg. B. Wiśniowski.

Lubelska Upland

Poleski National Park, Kulczyn (FB59), 1 female, 18.07.2007, leg. A. Onyszko, Urszulin (FB59), 1 female on the roadside, 14.07.2010, leg. W. Piotrowski.

\section{COMMENTS}

The presented new localities of Leucospis dorsigera are so far the most north-eastern sites of this species in Europe. The species was recently recorded also by other entomologists (Kośny \& Żyla, in print). Scolia hirta is distributed not only in the whole country but it was recorded in many new localities. Tabor and Ciach (2006) found 15 contemporary localities in Mazowiecka Lowland. 


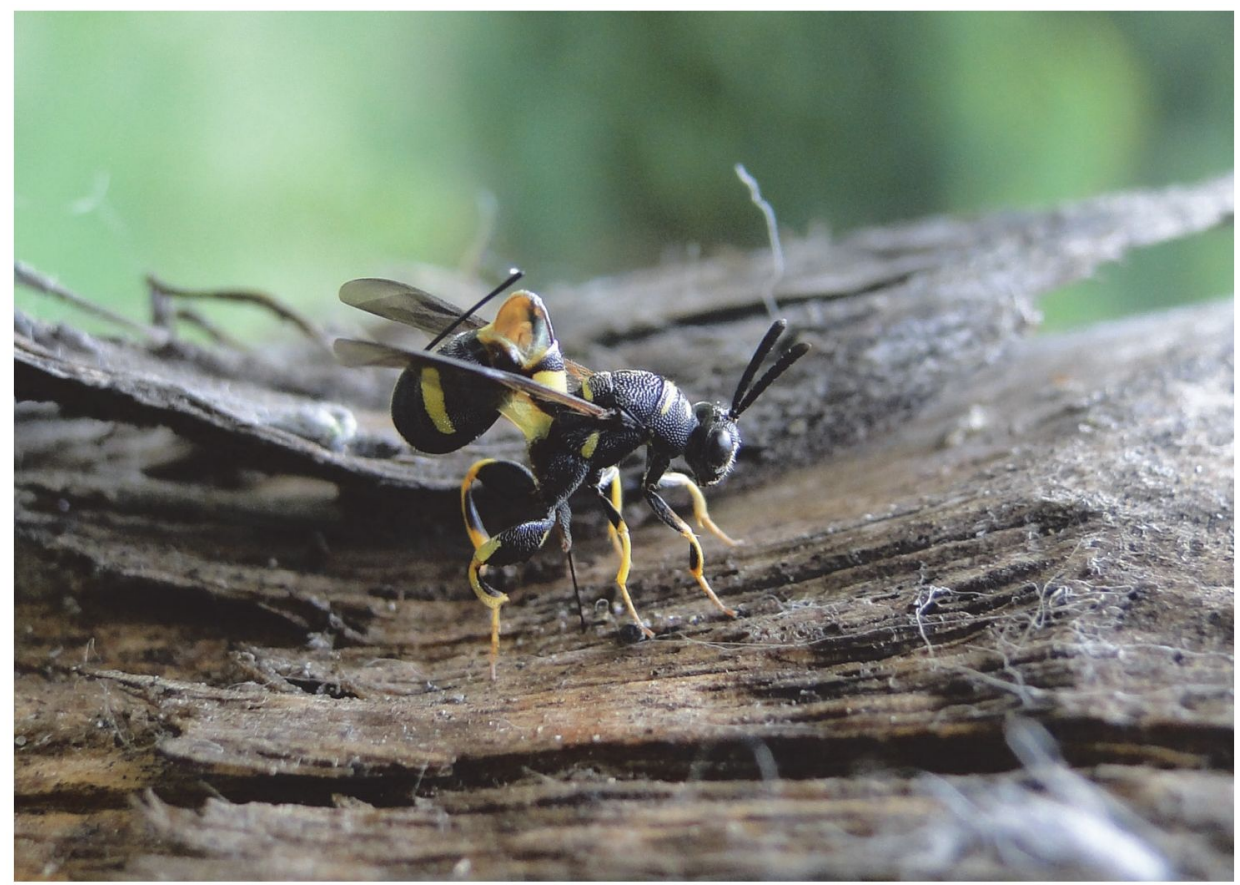

Fig. 1. Female Leucospis dorsigera, Kampinos National Park, village Pociecha (DC89), 22.06.2011, photo D. PepłowskaMarczak.

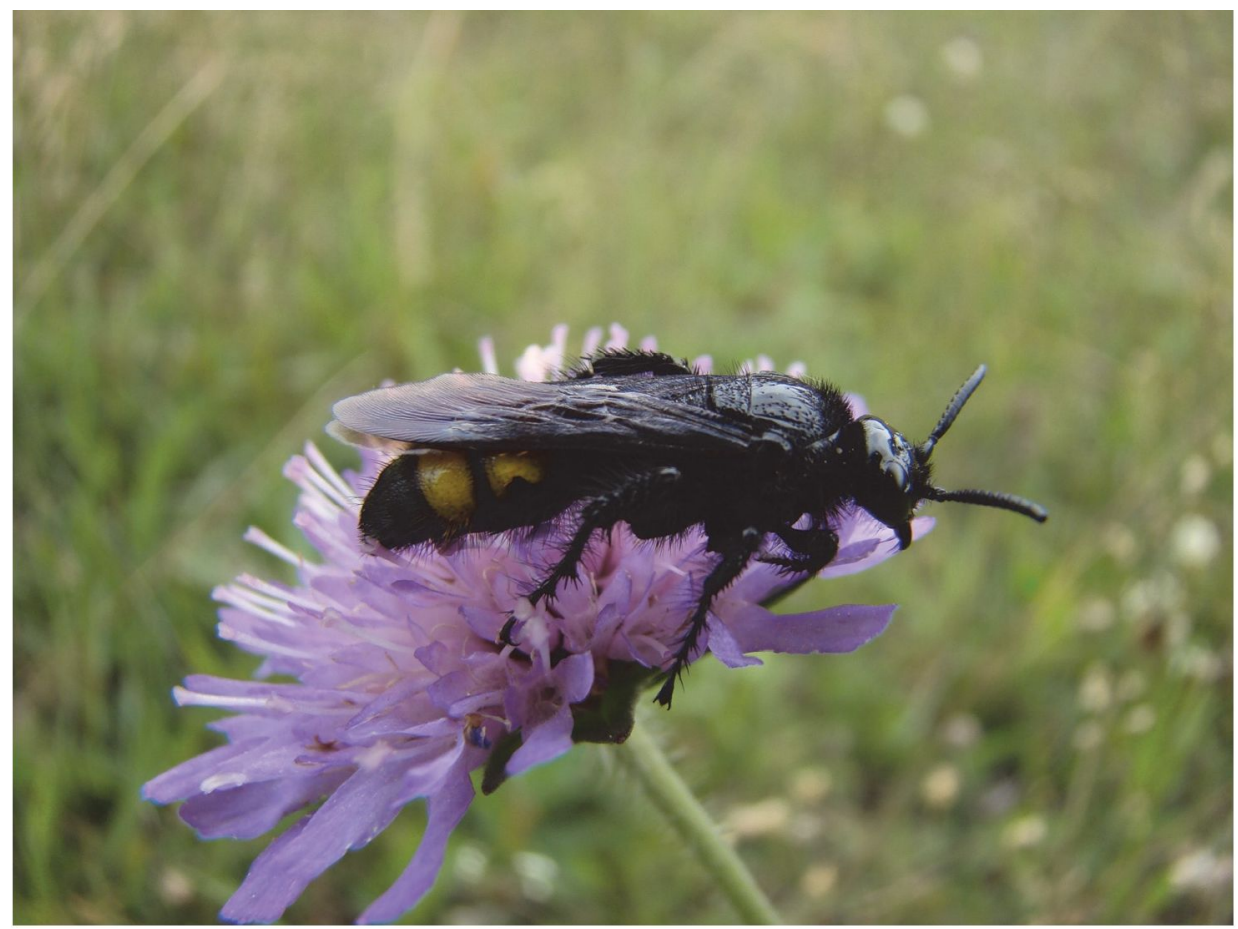

Fig. 2. Female Scolia hirta, Kampinos National Park, Niepust (DC89), 02.07.2011, photo D. Marczak. 
Quite frequent observations of both species in recent years may indicate that they become more common, as already stated for Scolia hirta by Banaszak and Twerd (2009). It is likely that the recent changes in nature conservation policy helped to recover Scolia hirta.

Psammophilous and grassland habitats, where the species occur, are now actively protected in Europe by Natura 2000 network. The active protection of the habitats listed in the annex of the Habitat Directive (mainly the communities Nardo-Callunetea, Koelerio glaucaeCorynephoretea canescentis and Festuco-Brometea), as well as their restoration and conservation may directly improve the protection of species such as Scolia hirta and other rare psammophilous wasps from the families Chrysididae, Sphecidae, Crabronidae and Pompilidae.

\section{ACKNOWLEDGEMENTS}

We would like to thank Professor Anna Liana for the information on the localities of Scolia hirta in Kampinos National Park, as well as Professor Jerzy M. Gutowski and other collectors for the specimens of $S$. hirta from other regions of Poland. Special thanks to Alexia HosteDanylow for the review of English.

\section{REFERENCES}

BanaszaK J. 2004. Smukwa kosmata Scolia hirta Schrank, 1781. In: GŁowaciński Z.\& NowaCKI J. (eds), Polish Red Data Book of Animals - Invertebrates, pp. 175-176. Institute of Nature Conservation, PAS, Kraków, 447 pp.

BANASZAK J. \& TWERD L. 2009. Historical and current records of Scolia hirta Schrank, 1781 (Hymenoptera: Scoliidae) in Poland. Polish Journal of Entomology 78: 101-110.

BAUR H. \& AMIET F. 2000. The Leucospidae (Hymenoptera: Chalcidoidea) of Switzerland, with a key and data on the European species. Revue Suisse de Zoolgie, 107, 2: 359-388.

BOUČEK Z. 1959. A revised key to the West-Palearctic species of Leucospis (Hym. Chalc.), with some new synonymy. Sbornik entomologickéko odděleni při zoologických sbirkách Národniho Musea v Praze 33: 435-444.

BOUČEK Z. 1974. A revision of the Leucospidae (Hymenoptera: Chalcidoidea) of the world. Bulletin of the British Museum Natural History Entomology, Suppl. 23: 241 pp.

FAUNA EUROPAEA 2011. Fauna Europaea version 2.4. Web Service available online at http://www.faunaeur.org

FEITZ F., SCHNEIDER N. \& PAULY A. 2003. Hyménoptères Apocrites nouveaux ou intéressants pour la faune luxembourgeoise (Hymenoptera, Apocrita). Bulletin de la Société des naturalistes luxembourgeois 104: 79-88.

GlowACIŃSKI Z.\& NowACKI J. (eds) 2004. Polish Red Data Book of Animals - Invertebrates. Institute of Nature Conservation, PAS, Kraków: 447 pp.

HesamI S., AKRAMI M. A. \& BAUR H. 2005. Lencospis dorsigera Fabricius (Hymenoptera, Leucospidae) as a hyperparasitoid of Cerambycidae (Coleoptera) through Xoridinae (Hymenoptera: Ichneumonidae) in Iran. Journal of Hymenoptera Research 14 (1): 66-68.

KoŚNY L., ŻYŁA W. (in print) Nowe stanowiska Leucospis dorsigera Fabricius, 1775 w Polsce. Acta Entomologica Silesiana.

MADL M. 1989. Zur Kenntnis der paläarktischen Leucospis-Arten unter besonderer Berücksichtigung der Fauna Österreichs (Hymenoptera, Chalcidoidea, Leucospidae). Zeitschrift für Entomologie 10 (212): 197-201.

MADL M. 1990. Beitrag zur Kenntnis der paläarktischen Leucospis-Arten unter besonderer Berücksichtigung der Fauna Österreichs (Hymenoptera, Chalcidoidea, Leucospidae). Linzer Biologische Beiträge 22 (1): 81-87.

PANZER G. W. F. 1798. Faunae insectorum Germanicae initia. Nürnberg, 58.

PAUly A., SchnNeIdER N., FEITZ F. \& VAGO J-L. 2002. Lencospis dorsigera Fabricius, 1775 (Hymenoptera : Chalcidoidea Leucospidae) au Luxembourg et dans le Nord-Est de la France. Notes fauniques de Gembloux 49: 126-129.

PeEters T. M. J.\& KuPER J. T. 2006. De wesp Lencospis dorsigera (Hymenoptera: Chalcidoidea: Leucospidae) nadert onze grens. Nieuwsbrief van de sectie Hymenoptera van de Nederlandse Entomologische Vereniging, 24: 62-64.

PUŁAWSKI W. 1964. Sapygidae, Scoliidae, Tiphiidae, Methocidae, Myrmosidae, Mutillidae. Klucze do oznaczania owadów Polski, XXIV, z. 57-62, Warszawa, 66 pp.

Rasomavicius V., Mierauskas P., Veein P., Tukaciauskas T., TRenvys R., Kazlauskas R. \&Vinskas D. 2006. Grasslands of Lithuania. Final Report on National Grassland Inventory 2002-2005. Lithuanian Fund for Nature, Royal Dutch Society for Nature Conservation. 56, online at www.veenecology.nl

RENNESON J.-L. 2005. Leucospis dorsigera Fabricius, 1775 (Hymenoptera: Chalcidoidea, Leucospididae): Espèce nouvelle en Belgique. Notes fauniques de Gembloux 56: 45-46. 
SZCZEPAŃSKI H. 1964. Bleskotki. In: Materialy konferencji „Stan badań nad organizmami pożytecznymi z punktu widzenia potrzeb ochrony roślin w Polsce", Skierniewice 8-9.05.1962. Zeszyty Problemowe Postępów Nauk Rolniczych 45: 159-165.

TABOR J. \& CIACH M. 2006. Stanowiska smukwy kosmatej Scolia hirta Schrank, 1781 (Hymenoptera: Scoliidae) na Nizinie Mazowieckiej. Kulon 11: 21-26.

WIŚNIOWSKI B. 2004. Osarek murarkowy Lencospis dorsigera FABRICIUS, 1775. In: GŁOWACIŃSKI Z. \& NOWACKI J. (eds), Polish Red Data Book of Animals - Invertebrates, pp. 223-224. Institute of Nature Conservation, PAS, Kraków, 447 pp.

WIŚNIOWSKI B. \& ŻYŁA W. 1996. Leucospis dorsigera Fabricius, 1775 (Hymenoptera: Chalcidoidea) w Polsce. Acta Entomologica Silesiana 4: 1-2.

\section{STRESZCZENIE}

[Nowe stanowiska dwóch rzadkich gatunków blonkówek (Hymenoptera): Leucospis dorsigera Fabricus, 1775 (Chalcidoidea: Leucospidae) i Scolia hirta Schrank, 1781 (Vespoidea: Scoliidae)]

W pracy przedstawiono nowe stanowiska dwóch rzadkich gatunków blonkówek. Pierwsza $\mathrm{z}$ nich - Leucospis dorsigera Fabr. (Chalcidoidea: Leucospidae) to parazytoid larw samotnie żyjących pszczól z rodziny Megachilidae. Jest gatunkiem zagrożonym, ze względu na zanikanie jego środowisk życia - starych, obumierających drzew na naslonecznionych siedliskach oraz drewnianego budownictwa. Dotychczas w Polsce znane byly tylko 4 stanowiska z poludniowej Polski. Autorzy podają kolejne 7 stanowisk z Polski centralnej i wschodniej przesuwajac tym samym pólnocno-wschodnia granicę zasięgu tego gatunku $\mathrm{w}$ Europie. Drugi gatunek - Scolia hirta (Vespoidea: Scoliidae) to parazytoid larw chrzaszczy z rodziny Scarabaeidae. Jest gatunkiem zagrożonym ze względu na zanikanie jego środowisk życia - muraw o charakterze kserotermicznym, spowodowane naturalną sukcesja zbiorowisk roślinnych. W Polsce gatunek znany jest z kilkudziesięciu stanowisk. Autorzy przedstawiaja kolejne lokalizacje tego gatunku w Polsce. 